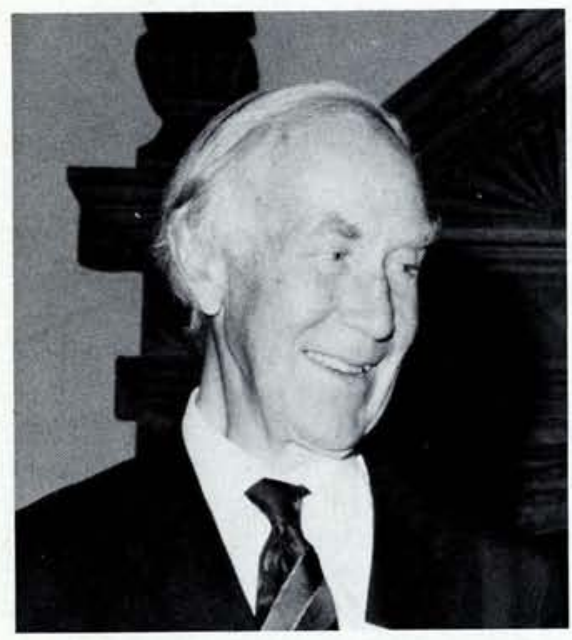

To the great regret of his many friends and colleagues the world over, Professor Erik Rudberg died on 2 January at Rönninge. He was 77.

Erik Rudberg was particularly well known to the members of EPS, having participated from the earliest days in the formation of the Society and its subsequent development. Member of the Steering Committee, the work of which led to the creation of the Society, he was chairman of the subgroup responsible for the drawing up of the Society's Constitution and ByLaws with the delicate and almost unique task of balancing the interests of individual and corporate members. Here, as in all he did, his energy, wisdom, experience and human gentleness were of inestimable value.

He saw in EPS a means for spreading international understanding and a bridge between countries with different political systems. He became the Society's second President, serving from 1970-1972, and courageously initiated the reappraisal of the Society's operations that led to the establishment under his successors of the sound financial basis upon which EPS is now run. During these past years, although retired, Erik Rudberg was still active in the life of the

\section{Erik RUDBERG}

Society and was to be seen in Rome last year, chairing one of the sessions of the Symposium on the European Great Projects with all the verve and courtesy of former years.

Erik Rudberg spent a full and very fruitful life in science, devoting his scientific research mainly to the physics and chemistry of metals. Educated in Göttingen, London and Boston (MIT) he became professor at Chalmers Institute of Technology in Göteborg in 1940. From 1945, he was the head of the Swedish Metallographic Institute and from 1959-1972 the Permanent Secretary of the Swedish Royal Academy of Sciences. For many years he was the chairman and member of the Nobel Committee for Physics - it was he who signed the cables announcing to many scientists their Nobel prize in physics and chemistry. Erik Rudberg was known not only as a scientist and a very able organizer of science and international contacts between scientists. He was a lover of Nature and enjoyed - until the very end - all kinds of physical activity: climbing - he was 67 when he climbed the Matterhorn - skiing, sailing, skating and hiking in the mountains. For many years he was the president of the Swedish mountaineering club and until the end of his life he frequently visited, inspected and took care of the Swedish natural reservation, and the biological and marine-biological stations of the Swedish Academy. It was in the middle of his beloved Swedish countryside that he lost his life.

Swedish scientists are not alone in mourning the death of Erik Rudberg, whose contribution to science and physics and international contacts and understanding in the "Community of Science" will not be forgotten.

Frantisek Janouch

\section{EPS Executive Committee}

In Budapest, Council elected as EPS Executive Committee for the year 1980/81:
President :
A.R. Mackintosh
Vice-President :
Secretary :
Kapitza
Vice-Secretary : H. de Waa
Treasurer: $\quad$ E.A. Müller
Vice-Treasurer : P. Radvanyi
Members :
J. Kaczer
W. Martienssen
A. Milojevic
G. Preparata
Z. Wilhelmi

\section{New I.O.M. Delegates}

Following the recent postal elections, the two new I.O.M. Delegates in place of the retiring members, $\mathrm{J}$. Fischer of Prague and J. Friedel of Paris, are :

M. Balkanski, Director of the Solid State Physics Laboratory of the Pierre and Marie Curie University of Paris, and

A. Messiah, Director of the Physics Division at the Commissariat à l'Energie Atomique laboratory of Saclay.

Balkanski is currently Chairman of the Board of the EPS Condensed Matter Division. In his election statement he said "it will be long and difficult to build up a real scientific community spanning all Europe, but this should not discourage us from believing in and working for it."

Messiah stated "all countries of Europe are confronted with similar problems in dealing with their research activities in physics now that the period of rapid expansion has ended. EPS is a good place to discuss these problems and help find solutions in keeping with the spirit of fundamental research."

First alternate is A. Budzanowski, Professor of the Institute of Nuclear Physics at the Cracow and Jagellonian University.

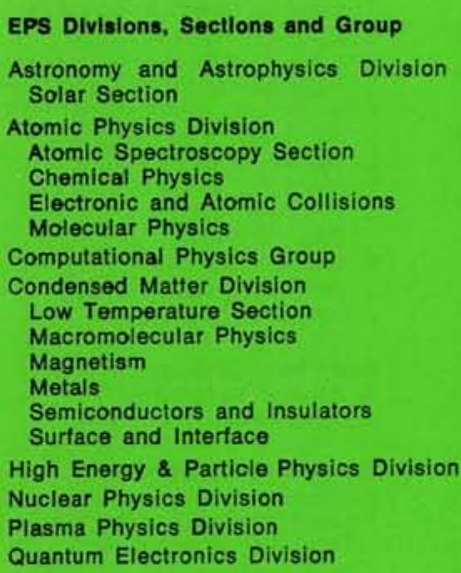

Europhysics News is the official journal of the European Physical Society that comprises $28 \mathrm{Na}$ tional Societies. Academies and Groups, over 3000 Individual Ordinary Members and 30 Asso3000 Individual Ordinary Members and General Meeting, Council and an elected Executive Committee responsibie for detalled policy EPS promotes the collaboration of physicists throughout Europe and encourages all aspects o international exchange in physics. EPS award international exchange in physics. EPS awards countries. EPS publishes, in addition to Europhyscountries. EPS publishes, in addition to Europhys
ics News, Europhysics Conference Abstracts, Euics News, Europhysics Conference Abstracts, Eu its General Conferences. Individual Ordinary Members receive Europhysics News (subscription for non-Members: $75 \mathrm{Sw}$. Fr./a), substantial rebates on many publications and pay reduced fees tes on many pubilcations and pay rember at conterences. Application for membership is made through the permanent Secretariat in
Geneva. Annual subscription for members of a National Society from 1 January, 1980 is 32 Sw.Fr.

\section{Editor : E.N. Shaw}

Meetings Compllation: W.S. Newman

Editorial Board :

K. Appert, A. Baratoff, G.J. Béné, G.R. Macleod, A. Maeder, J. Muller

Editorial and Advertising Office at the EPS Secretarlat.

Address: EUROPEAN PHYSICAL SOCIETY P.0. Box 69, CH-1213 Petlt-Lancy 2 Switzerland

Telephone : Geneva (22) 931130

Telex : 23455 alarm ch

Cables: europhys genève

Printed by : Ed. Cherix et Fllanosa SA CH-1260 Nyon, Swltzerland 